\title{
Entry of Phenuiviruses into Mammalian Host Cells
}

\author{
Jana Koch ${ }^{1,+}+\mathbb{D}$, Qilin Xin ${ }^{2,+}+\mathbb{D}$, Nicole D. Tischler ${ }^{3}(\mathbb{D})$ and Pierre-Yves Lozach $1,2, *(\mathbb{D}$ \\ 1 CellNetworks-Cluster of Excellence and Center for Integrative Infectious Diseases Research (CIID), \\ Department of Infectious Diseases, Virology, University Hospital Heidelberg, 69120 Heidelberg, Germany; \\ jana.koch@med.uni-heidelberg.de \\ 2 INRAE, EPHE, Viral Infections and Comparative Pathology (IVPC), UMR754-University Lyon, \\ 69007 Lyon, France; qilin.xin@etu.univ-lyon1.fr \\ 3 Fundación Ciencia \& Vida, Molecular Virology Laboratory, Universidad San Sebastián, \\ 7780272 Santiago, Chile; ntischler@cienciavida.org \\ * Correspondence: pierre-yves.lozach@med.uni-heidelberg.de \\ + These authors contributed equally to this work.
}

Citation: Koch, J.; Xin, Q.; Tischler, N.D.; Lozach, P.-Y. Entry of Phenuiviruses into Mammalian Host Cells. Viruses 2021, 13, 299. https://doi.org/10.3390/v13020299

Academic Editors: Esther Schnettler and Benjamin Brennan

Received: 16 January 2021

Accepted: 11 February 2021

Published: 14 February 2021

Publisher's Note: MDPI stays neutral with regard to jurisdictional claims in published maps and institutional affiliations.

Copyright: (c) 2021 by the authors. Licensee MDPI, Basel, Switzerland. This article is an open access article distributed under the terms and conditions of the Creative Commons Attribution (CC BY) license (https:// creativecommons.org/licenses/by/ $4.0 /)$.

\begin{abstract}
Phenuiviridae is a large family of arthropod-borne viruses with over 100 species worldwide. Several cause severe diseases in both humans and livestock. Global warming and the apparent geographical expansion of arthropod vectors are good reasons to seriously consider these viruses potential agents of emerging diseases. With an increasing frequency and number of epidemics, some phenuiviruses represent a global threat to public and veterinary health. This review focuses on the early stage of phenuivirus infection in mammalian host cells. We address current knowledge on each step of the cell entry process, from virus binding to penetration into the cytosol. Virus receptors, endocytosis, and fusion mechanisms are discussed in light of the most recent progress on the entry of banda-, phlebo-, and uukuviruses, which together constitute the three prominent genera in the Phenuiviridae family.
\end{abstract}

Keywords: arbovirus; arthropod; bandavirus; cell entry; emerging virus; endocytosis; fusion; Heartland; phlebovirus; receptor; Rift; RNA virus; SFTSV; Toscana; Uukuniemi; uukuvirus

\section{Introduction}

Phenuiviridae in the Bunyavirales order is a large family of arthropod-borne RNA viruses that comprises 19 genera [1,2]. Phenuiviruses are unique in the sense that they infect a large spectrum of hosts, including humans and other vertebrates as well as invertebrates and plants. They usually spread to vertebrate hosts by blood-feeding arthropod vectors, such as sandflies and ticks and more rarely mosquitoes [3]. With over 100 identified members and a wide geographical distribution, phenuiviruses represent a global threat to human public health and livestock and agricultural productivity [4]. Many members cause serious diseases in humans and domestic animals. For instance, in severe cases, patients infected with Dabie virus (DABV) develop thrombocytopenia and hemorrhagic fever, resulting in a case-fatality rate of 10-30\% [5]. Toscana virus (TOSV) can cause meningoencephalitis in humans, and Rift Valley fever virus (RVFV) acute hepatitis and fetal malformations in several mammalian hosts including cattle [6-8]. No vaccines or treatments against phenuiviruses are currently approved for human use.

Human activity, international trade, deforestation, and global warming are many of the factors favoring the spread of arthropod vectors to new regions as well as the viruses they carry. Many examples show that phenuiviral infections are no longer limited to tropical or developing countries. DABV, previously known as severe fever with thrombocytopenia syndrome virus (SFTSV), and Heartland virus (HRTV), are two closely related members in the Bandavirus genus transmitted by the Haemaphysalis longicornis and Amblyomma americium ticks, respectively $[5,9,10]$. DABV emerged in Henan and Hubei provinces, China, and HRTV in Missouri, USA, one decade ago [5,11-14]. The emergence of these two human 
pathogens led to a renewed interest in the study of Uukuniemi virus (UUKV), an uukuvirus originally isolated from the Ixodes ricinus tick in the village Uukuniemi, Finland, in the early 1960s [15]. UUKV is not associated with any disease in humans. It is a validated biosafety level (BSL)-2 surrogate that enabled major advances in many aspects of the cell life cycle of phenuiviruses with a higher biosafety classification, such as receptors, cell entry, and assembly [16-18].

The Phlebovirus genus includes members that also illustrate the need to seriously take phenuiviruses as potential agents of emerging and reemerging diseases. The phlebovirus Toscana was first isolated in 1971 from Phlebotomus perniciosus and Phlebotomus perfiliewi sandflies in the Tuscany region, Italy [19]. The virus is reemerging in the Mediterranean basin, as shown by the increasing number of outbreaks and reported cases in Spain, south of France, Italy, and Greece $[6,20,21]$. TOSV is currently the primary cause of arboviral diseases in humans in southern Europe during the summer [6,22]. Another example is RVFV, a phlebovirus transmitted essentially by Aedes and Culex mosquitoes [23]. The virus was discovered in the Great Rift Valley, Kenya, in 1930 [24] and has since spread across Africa and beyond in the 1970s to reach Madagascar and, more recently, Saudi Arabia and Turkey $[7,8,25]$. RVFV now presents the risk of introduction into southern Europe and Asia. It is listed as high-priority pathogens by the World Health Organization, for which there is an urgent need to develop diagnostics, therapies, and research [26]. The virus is in addition considered as a potential biological weapon by the US army. Overall, it is apparent that phleboviruses and other phenuiviruses are potential agents of emerging and reemerging diseases.

In 2016, we contributed to the first special issue on bunyaviruses from Viruses with a review on early bunyavirus-host cell interactions [27]. Since then, important discoveries have been made in this field. Taxonomic classification has evolved considerably to better reflect the variety of bunyavirus members, vectors, hosts, and diseases $[1,2,28]$. In this review, we therefore focus on the novel family Phenuiviridae. We address the most current knowledge and advances regarding the entry process of phenuiviruses, from virus binding to penetration into the cytosol. Most of the available information on how phenuiviruses enter cells comes from studies on only a few species, mainly banda-, phlebo-, and uukuviruses infecting animals (Table 1). Nothing is known about the penetration mechanisms in plant cells, and not much regarding penetration in arthropod cells. Hence, the discussion is limited to animal phenuiviruses and mammalian host cells. For information on phenuiviruses and their arthropod vectors, we recommend the following reviews [4,23,29-31].

Table 1. Classification within the family of Phenuiviridae $[1,2]$.

\begin{tabular}{ccc}
\hline Genus & Species & Representative Species \\
\hline Bandavirus & 7 & $\begin{array}{c}\text { Dabie bandavirus [previously named severe fever with } \\
\text { thrombocytopenia syndrome virus (SFTSV)] } \\
\text { Heartland bandavirus (HRTV) }\end{array}$ \\
\hline Beidivirus & 1 & Dipteran beidivirus \\
\hline Cugovirus & 2 & Citrus coguvirus \\
\hline Entovirus & 1 & Entoleuca entovirus \\
\hline Goukovirus & 3 & Gouleako goukovirus \\
\hline Horwuvirus & 1 & Horsefly horwuvirus \\
\hline Hudivirus & 1 & Dipteran hudivirus \\
\hline Hudovirus & 1 & Lepidopteran hudovirus \\
\hline Ixovirus & 3 & Blackleg ixovirus \\
\hline Laulavirus & 1 & Laurel Lake laulavirus \\
\hline Lentinuvirus & 1 & Lentinula lentinuvirus \\
\hline
\end{tabular}


Table 1. Cont.

\begin{tabular}{lcc}
\hline Genus & Species & Representative Species \\
\hline Mobuvirus & 1 & Mothra mobuvirus \\
\hline Phasivirus & 5 & Badu phasivirus \\
\hline Phlebovirus & 60 & $\begin{array}{c}\text { Rift Valley fever phlebovirus (RVFV), Punta Toro phlebovirus } \\
(\text { PTV), Sandfly fever Sicilian phlebovirus (SFSV), Sandfly fever } \\
\text { Naples phlebovirus (SFNV), Toscana phlebovirus (TOSV) }\end{array}$ \\
\hline Pidchovirus & 1 & Pidgey pidchovirus \\
\hline Rubodvirus & 2 & Apple rubodvirus 1 \\
\hline Tenuivirus & 8 & Rice stripe tenuivirus \\
\hline Uukuvirus & 17 & Uukuniemi uukuvirus (UUKV) \\
\hline Wenrivirus & 1 & Shrimp wenrivirus \\
\hline The genera and species highlighted in this review appear in bold and underlined, respectively.
\end{tabular}

\section{Genomic and Structural Organization of Phenuiviral Particles}

Phenuiviruses are enveloped by a lipid bilayer with a trisegmented single-stranded RNA genome, mainly of negative-sense polarity (Figure 1a) [4]. The viral RNA replicates exclusively in the cytosol and encodes at least four structural proteins [4]. The longest segment of genomic RNA, the L segment, encodes an RNA-dependent RNA polymerase, which is necessary to initiate virus replication after release of the viral genome into the cytosol. The medium segment, $\mathrm{M}$, encodes a precursor polypeptide for the two envelope glycoproteins $\mathrm{G}_{\mathrm{N}}$ and $\mathrm{G}_{\mathrm{C}}$ (Figure $1 b$ ) [32,33]. Phenuiviruses also encode one or two nonstructural proteins, i.e., NSs and NSm. With the vector of transmission, the presence of an NSm protein appears as one of the main distinctions between tick- and dipteran-borne phenuiviruses [4]. Although phenuiviruses are quite distinct from each other, analysis of amino-acid sequences revealed that the structural proteins of phenuiviruses show a rather high similarity in general, up to $30-40 \%$, compared to the nonstructural proteins, about $10-15 \%[4,5,34]$. So far, none of the nonstructural proteins has been shown to be involved in virion cell entry and will therefore not be discussed here.

Proteolytic cleavage of the $\mathrm{M}$ precursor takes place in the endoplasmic reticulum or Golgi apparatus, where the virions assemble and acquire their lipid envelope. The exact location and mechanisms of $\mathrm{G}_{\mathrm{N}}$ and $\mathrm{G}_{\mathrm{C}}$ glycoprotein maturation and viral particle budding may differ between phenuiviral species and cell types. They often remain to be elucidated. The smallest segment $S$ encodes the nucleoprotein $N$, which, together with polymerase and viral RNA, constitute the ribonucleoproteins found inside virions (Figure 1a) [4]. Phenuiviruses do not have a classical matrix or a rigid internal structure. The $\mathrm{N}$ protein therefore plays an important role in protecting the genetic information of these viruses. In recent years, the crystal structure of the $\mathrm{N}$ protein has been resolved for several phenuiviruses, providing new information on the mechanisms of ribonucleoprotein assembly [35].

On the surface of viral particles, the two envelope glycoproteins $G_{N}$ and $G_{C}$ are responsible for virion binding to the target cells and then acid-activated penetration into the cytosol [3]. Electron micrographs show that phenuiviral particles are globally spherical and heterogeneous in size, with a diameter ranging from 80 to $160 \mathrm{~nm}$ [4]. Electron cryo-tomography analyses of RVFV and UUKV revealed that the most regular particles have protrusions on their surface forming an icosahedral lattice with an atypical $\mathrm{T}=12$ triangulation (Figure 1c) [36-38]. 
(a)

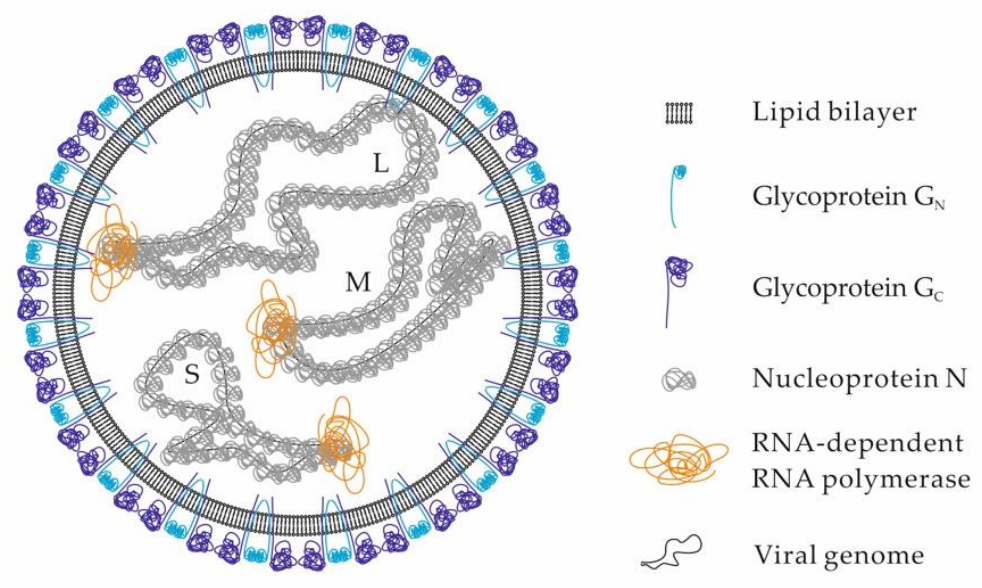

(b) $80-160 \mathrm{~nm}$

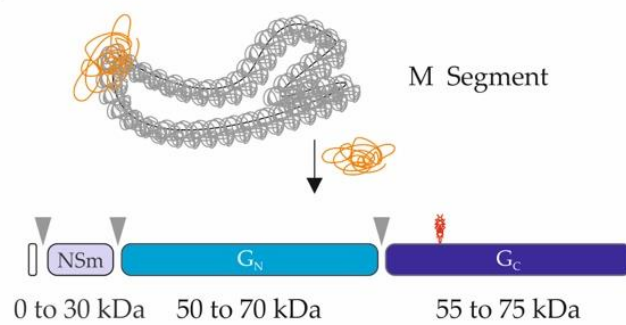

Fusion unit (predicted)

$\checkmark$ Unknown host proteases

Signal peptide

0 to $30 \mathrm{kDa} \quad 50$ to $70 \mathrm{kDa}$

55 to $75 \mathrm{kDa}$

(c)

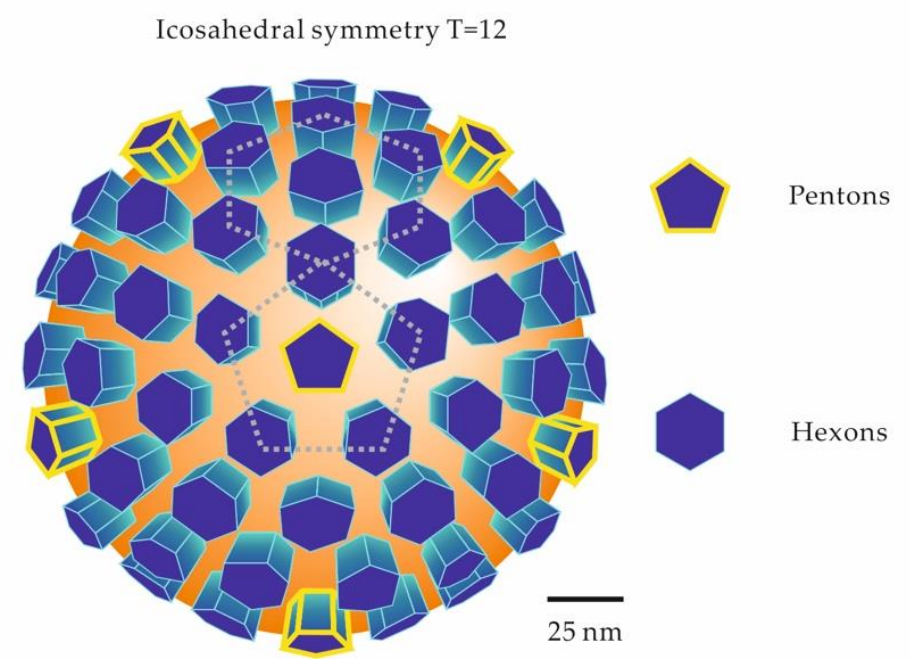

Figure 1. Phenuiviral particles and the glycoproteins $G_{N}$ and $G_{C}$. (a) Schematic representation of a phenuiviral particle. The three viral genomic RNA segments are named according to their size: $\mathrm{S}$ (small), M (medium), and L (large). (b) Proteolytic processing of the phenuivirus M polypeptide precursor. The $M$ precursor and the glycoproteins $G_{N}$ and $G_{C}$ can vary greatly among phenuiviral species. In addition to $G_{N}$ and $G_{C}$, some phenuiviruses encode an additional nonstructural protein, NSm. Arrow heads indicate the cleavage sites by host cell proteases within the precursor. The position of the fusion peptide is given based on the crystal structure of the Rift Valley fever virus (RVFV) glycoprotein $G_{C}$ [39]. (c) Arrangement of $G_{N}$ and $G_{C}$ glycoproteins on the surface of phenuiviral particles. Electron cryo-tomography analysis of RVFV [36,37] and Uukuniemi virus (UUKV) [38] viral particles shows an icosahedral lattice with an atypical $\mathrm{T}=12$ triangulation. 


\section{Cellular Receptors for Phenuiviruses in Mammalian Hosts}

To initiate infection, viruses must first attach to target cells and then obtain access to the intracellular environment to replicate. The first step is highly dependent on the presence of surface receptors, such as proteins, lipids, or carbohydrates, to which viral particles bind [40]. Some of these receptors by themselves are capable of triggering the entry of viral particles into the cell. Others limit the free diffusion of virions and/or promote interactions with secondary surface molecules that are responsible for the entry of viral particles [40]. When viruses depend on numerous cellular surface factors for binding and entry, the primary receptor is often referred to as an attachment factor, and the secondary receptors are referred to as coreceptors. Only a few attachment factors and receptors are known for phenuiviruses, and very often, their role in cell entry remains to be discovered (Table 2).

Table 2. Receptors for phenuiviruses in mammalian hosts.

\begin{tabular}{ccc}
\hline Receptor/Cofactor & Species & References \\
\hline DC-SIGN & DABV, ppDABV, PTV, RVFV, TOSV, UUKV & {$[41-45]$} \\
\hline L-SIGN & ppDABV, RVFV, TOSV, UUKV & {$[42,43,46,47]$} \\
\hline LSECtin & ppDABV & {$[43]$} \\
\hline Heparan sulfates & RVFV, TOSV & {$[48-50]$} \\
\hline NMMHC-IIA & DABV & {$[51]$} \\
\hline
\end{tabular}

DABV, Dabie virus; DC-SIGN, dendritic cell-specific intercellular adhesion molecule-3-grabbing non-integrin L-SIGN, liver-specific intercellular adhesion molecule-3-grabbing non-integrin; LSECtin, liver and lymph node sinusoidal endothelial cell C-type lectin; NMMHC-IIA, nonmuscle myosin heavy chain IIA; ppDABV, rhabdovirus pseudotyped with the glycoproteins $\mathrm{G}_{\mathrm{N}}$ and $\mathrm{G}_{\mathrm{C}}$ of Dabie virus; PTV, Punta Toro virus; RVFV, Rift Valley fever virus; TOSV, Toscana virus; UUKV, Uukuniemi virus.

Interactions between viruses and receptors are often specific and multivalent. Binding to several molecules of the same receptor, concentrating within microdomains, may increase the avidity of low-affinity interactions [40]. For example, glycoproteins and glycolipids present in the extracellular matrix of most mammalian cells are highly polar structures. Despite low affinity interactions, due to their electrostatic nature, these structures serve as attachment factors for many viruses, including phenuiviruses. Glycosaminoglycans (GAGs), such as heparan sulfates, have been shown to facilitate RVFV and TOSV infections (Table 2) [48-50]. Infection with these two viruses is greatly reduced in the presence of heparin, a competitor of GAGs on the cell surface. In addition, enzymatic digestion of heparan sulfate on the cell surface prior to exposure to these viruses produces similar results. Finally, cells deficient in heparan sulfate synthesis show a reduced sensitivity to RVFV [48,49]. Interestingly, the glycoproteins of an RVFV strain amplified in cell culture and used in one of these studies do not differ in basic amino acid composition from those on viruses isolated from infected animals [48]. This result suggests that the dependence of RVFV on heparan sulfates does not result from the adaptation of the virus to cell culture. However, the fact that some cell types remain permissive to infection even without GAGs indicates that phenuiviruses may use alternative receptors to enter cells.

A number of studies have indicated that many phenuiviruses can use the human C-type lectin DC-SIGN (also known as CD209) to target and infect dendritic cells (DCs) in the dermis (Table 2) [41-45]. In the presence of neutralizing antibodies, dermal DCs become resistant to infection with RVFV and UUKV [41]. The expression of DC-SIGN at the plasma membrane renders cells that are originally not permissive highly sensitive to several phleboviruses, including RVFV, UUKV, TOSV and Punta Toro virus [41]. The list of phleboviruses described to interact with DC-SIGN has since been extended to include bandaviruses. Recent studies demonstrate, among others, that lectin facilitates infection by DABV or rhabdoviral particles pseudotyped with DABV glycoproteins [42-44]. DC-SIGN represents an interesting molecular candidate for linking arthropod-derived viruses to the initial infection in the skin of the human host. This immune receptor is (i) mainly expressed 
on the surface of immature dermal DCs present in the anatomical site of transmission of these viruses and (ii) specialized in the capture of foreign antigens rich in mannose residues, such as the glycoproteins found in viruses produced from insects [3,41]. For these reasons, interactions between DC-SIGN and arthropod-borne pathogens are considered the most relevant, although several studies have suggested a role of lectin in infection by various microbes not propagated by arthropods [52].

Phenuiviruses generally possess numerous $N$-glycosylations on the particle surface, distributed between the envelope glycoproteins $\mathrm{G}_{\mathrm{N}}$ and $\mathrm{G}_{\mathrm{C}}[33,53]$. For instance, RVFV has one glycosylation site in $\mathrm{G}_{\mathrm{N}}$ and four in $\mathrm{G}_{\mathrm{C}}$. RVFV appears to rely on the $N$-glycan sites $\mathrm{N} 438$ and $\mathrm{N} 1077$ in $\mathrm{G}_{\mathrm{N}}$ and $\mathrm{G}_{\mathrm{C}}$, respectively, for DC-SIGN-mediated infection [45]. It is tempting to draw a parallel with dengue virus in the Flaviviridae family and its envelope glycoprotein E. The engagement of multiple E molecules by homotetramers of DC-SIGN explains the high avidity of the interaction between the lectin and the viral particles [54]. The same is probably true for the interactions between DC-SIGN and phenuiviruses. In addition, the human C-type lectins L-SIGN and LSECtin, both closely related to DC-SIGN but expressed on the surface of the liver endothelium [55], are also used as receptors by several phenuiviruses, including RVFV, TOSV, UUKV, and DABV (Table 2) $[42,43,46,47]$. It is possible that L-SIGN and LSECtin, by acting as receptors on the surface of the liver endothelium, contribute to the hepatic tropism of some phenuiviruses.

Nonmuscle myosin heavy chain type IIA (NMMHC-IIA) has been proposed to act as an attachment factor for DABV (Table 2) [51]. This factor has been identified using a strategy combining coimmunoprecipitation and mass spectrometry analysis, using a fragment of the $\mathrm{G}_{\mathrm{N}}$ ectodomain as bait. NMMHC-IIA usually has an intracellular localization but, in some cases, seems to be able to reach the outer surface of the plasma membrane, notably in human umbilical vein endothelial cells and Vero cells [51]. Silencing of the gene coding for NMMHC-IIA by small interfering RNAs (siRNAs) led to a significant decrease in infection by DABV. It is likely that NMMHC-IIA is not the only cellular receptor used by DABV. HeLa cells do not express this gene and are sensitive to infection [51]. However, ectopic expression of NMMHC-IIA resulted in an increased sensitivity of HeLa cells to DABV. It is still not known whether NMMHC-IIA serves as an entry receptor or simply as an attachment factor.

More recently, DABV has been observed in secreted vesicles exhibiting CD63, a marker of extracellular vesicles (Table 2) [56]. It appeared that virions within these vesicles are efficiently delivered to neighboring uninfected cells. This work was the first demonstration of the hijacking of the exocytosis machinery by a phenuivirus to ensure its transmission to surrounding cells in a receptor-independent fashion.

\section{Internalization of Phenuiviruses into Cells}

To be internalized and enter the host cell, phenuiviruses depend on the endocytic machinery. The number of studies on the endocytic receptors and pathways used by phenuiviruses has increased significantly in recent years (Table 3). However, after the attachment of virions to their receptor(s), the process of passage from the outside to the inside of the cell remains to be discovered for most phenuiviruses (Figure 2). By combining the use of fluorescently-labeled UUKV particles [57] and the expression of green fluorescent protein-tagged DC-SIGN molecules, it was possible to visualize virus-receptor interactions in living cells for the first time [41]. This model has made it possible to analyze the dynamics of these interactions and, in particular, to observe the recruitment of receptor molecules to the UUKV binding site on the cell surface [41]. This supports the hypothesis that some viruses aggregate their receptors at the site of contact, thus generating a receptor-enriched microdomain at the plasma membrane. Such a series of events is probably a precondition for local curvature of the plasma membrane and for the transduction of receptor-mediated signals to induce the internalization of virions into the endocytic machinery [40].

Cholesterol and other lipids also most certainly play a role in the early mechanisms of virus-receptor interactions by promoting the formation of anchoring sites for cellular 
cofactors. A study on DABV and HRTV entry into cells lacking glucosylceramide synthase activity suggests that this is also the case for phenuiviruses [58]. The authors show that the entry program of DABV, as well as that of HRTV, is greatly disrupted in the absence of this enzyme. Glucosylceramide synthase is involved in the maturation of ceramides, and the abrogation of its activity leads to a major change in the lipid composition of the plasma membrane and the resulting endosomal vesicles.

Amino acid motifs in the cytosolic tails of receptors generally define the identity of the endocytic pathway by which the cargo is internalized. These motifs serve as binding sites for specific proteins with functions in signaling and endocytosis [40]. The cytosolic tail of DC-SIGN contains several of these motifs, including two leucines (LL) critical for the internalization of the cargo by the lectin [59]. DC-SIGN mutants lacking the dileucine motif capture UUKV with the same efficiency as the wild-type receptor [41]. However, the virus is no longer internalized, and the infection is abolished. Interestingly, LL-based motifs are usually associated with adaptor proteins and clathrin-mediated uptake $[60,61]$, and DC-SIGN was found to colocalize with microdomains enriched in clathrin [62,63]. Overall, this result shows that DC-SIGN serves in this case as an "endocytic" receptor, and not only as an attachment factor. Unlike the case for DC-SIGN, the endocytic function of L-SIGN is not required for UUKV infection [47]. Infection was similar whether cells expressed the wild-type lectin or its endocytic-defective mutant. This result indicates a fundamental difference in the use of DC-SIGN and L-SIGN by phenuiviruses for cell entry. In summary, DC-SIGN is an endocytic receptor for phenuiviruses whereas L-SIGN is an attachment factor. No other signal motif in receptors has been identified for phlebo-, uuku-, and bandaviruses with a function in virus internalization and productive entry.

Table 3. Cellular factors and processes important for phenuivirus infectious entry.

\begin{tabular}{|c|c|c|c|}
\hline \multirow{2}{*}{ Virus } & \multirow{2}{*}{ Fusion/Penetration } & \multicolumn{2}{|c|}{ Cellular Factors in Viral Entry } \\
\hline & & Required & Not Required \\
\hline DABV & $\begin{array}{c}\mathrm{pH} \mathrm{5.6}[64] \\
60 \min (\max )[64]\end{array}$ & $\begin{array}{c}\text { Actin [64], } \mathrm{Ca}^{2+} \text { channels [65], clathrin [64], } \\
\text { dynamin-2 [42,64], glucosylceramide synthase [58], } \\
\text { LAMP1 [66], microtubules [64], serine proteases } \\
\text { [42], Rab5 [64,66], Rab7 [64,66], SNX11 [66], } \\
\text { vATPases [42] }\end{array}$ & $\begin{array}{c}\text { Gangliosides series a and b [58], } \\
\text { cathepsin B and L [42], caveolin-1 } \\
\text { [64], cholesterol [64], } \\
\text { lactosylceramide synthase [58], PAK1 } \\
\text { [64], PI3K [42], Rab7 [58], Rac1 [64] }\end{array}$ \\
\hline HRTV & & Glucosylceramide synthase [58] & \\
\hline RVFV & $\begin{array}{c}\mathrm{pH} 5.7[67] \\
16-24 \min \left(\mathrm{t}_{1 / 2}\right)[67]\end{array}$ & $\begin{array}{c}\text { Actin [68], } \mathrm{Ca}^{2+} \text { and } \mathrm{K}^{+} \text {channels [68], caveolin-1 } \\
\text { [69], cholesterol [69], clathrin [67], dynamin-2 } \\
{[67,69], \mathrm{Na}^{+} / \mathrm{H}^{+} \text {exchangers [68], microtubules }} \\
\text { [68], PI3K [68], PKC [68], PLC [68], PP1/PP2A [69], } \\
\text { RNASEK [70], vATPase [67,69] }\end{array}$ & $\begin{array}{l}\text { Actin [67,69], cholesterol [67], clathrin } \\
\text { [69], } \mathrm{Na}^{+} / \mathrm{H}^{+} \text {exchangers [69], Eps15 } \\
\text { [69], PAK1 [69], PI3K [69], Rac1 [69] }\end{array}$ \\
\hline UUKV & $\begin{array}{c}\mathrm{pH} 5.4[71] \\
20-30 \min \left(\mathrm{t}_{1 / 2}\right)[71]\end{array}$ & $\begin{array}{l}\text { BMP [72], clathrin [71], HDAC8 [73], LAMP1 [71], } \\
\text { microtubules [71], PI3K [71], Rab5 [71], RNASEK } \\
\text { [74], temperature [71], VAMP3 [74], vATPase [71] }\end{array}$ & $\operatorname{Rab7}[71]$ \\
\hline
\end{tabular}

The cellular factors in blue have been described by independent studies as either required or not required in the cellular entry of the virus. BMP, bis(monoacylglycerol)phosphate; DABV, Dabie virus; HDAC, histone deacetylase 8, LAMP1, lysosome-associated membrane protein 1; PAK1, p21-activated kinase 1; PI3K, phosphoinositide 3-kinase; PLC, phospholipase C; PKC, protein kinase C; PP1/PP2A, protein phosphatase 1/2A; Rab5 and Rab7, Ras-related protein 5 and 7; RVFV, Rift Valley fever virus; RNASEK, ribonuclease K; TOSV, Toscana virus; UUKV, Uukuniemi virus; VAMP3, vesicle-associated membrane protein 3; vATPase, vacuolar-type proton pump ATPase.

A recent study suggests that DABV uses the clathrin-mediated endocytosis pathway to enter cells (Figure 2; Table 3) [64]. In cells expressing DC-SIGN, electron microscopy images show that UUKV particles enter clathrin-coated vesicles but not only these vesicles [41]. In non-lectin-expressing cells, such events are very rarely observed for UUKV [71]. Moreover, silencing of the clathrin heavy chain gene by siRNA has no significant impact on UUKV infection (Table 3) [71]. It is also unclear whether other phenuiviruses use the clathrinmediated endocytosis to enter cells (Table 3). It has been proposed that a genetically engineered, nonspreading strain of RVFV relies on clathrin for productive entry [67]. 
Conversely, two reports suggested that the vaccine strain MP12 enters cells independently of clathrin. The first indicated a role of actin and many kinases with functions related to macropinocytosis (Table 3). These authors proposed that RVFV relies on macropinocytosis for entry [68]. The second study rather pointed out caveolin, implying that RVFV entry occurs through caveolin-dependent mechanisms (Table 3) [69].

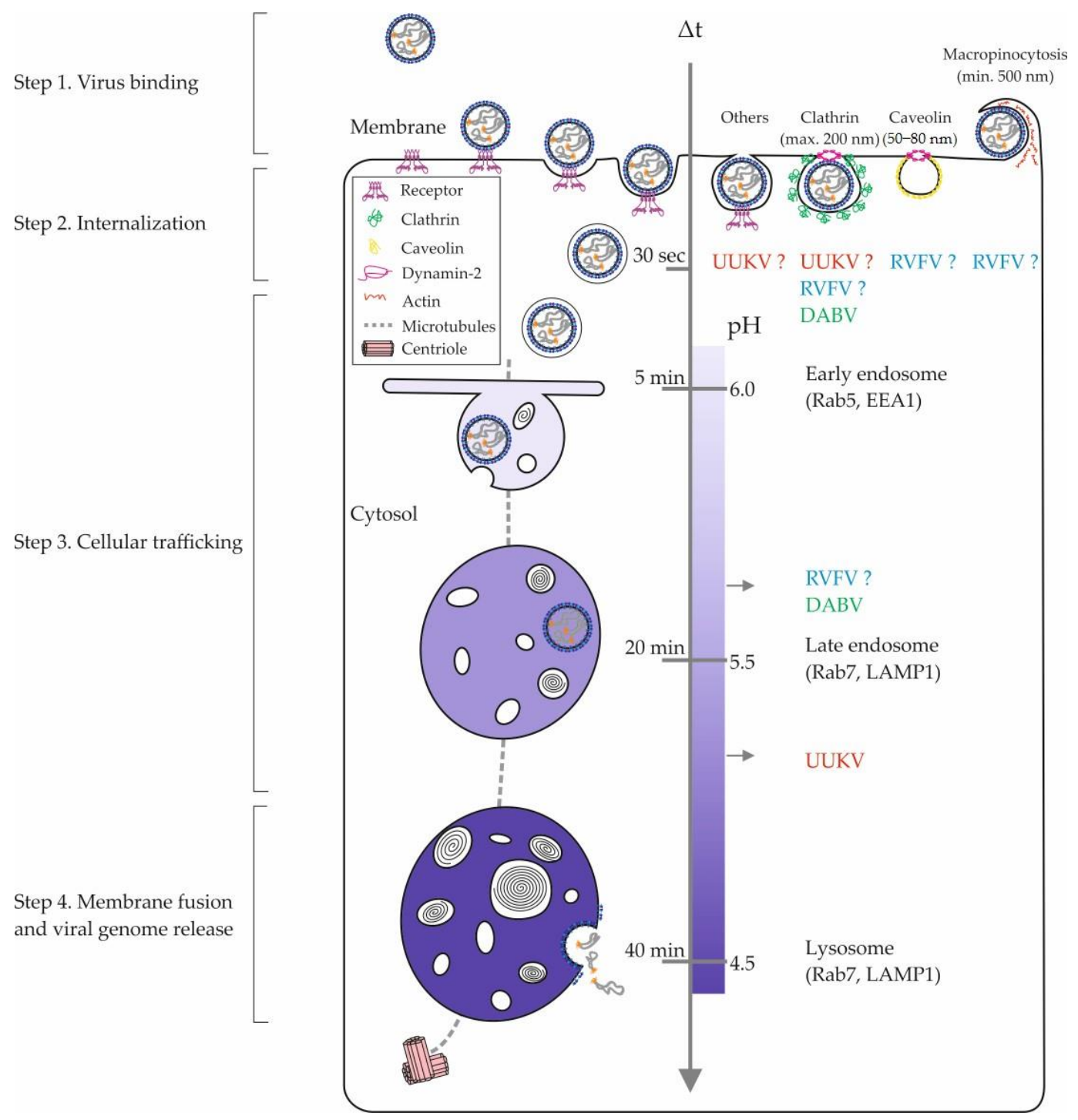

Figure 2. Phenuivirus endocytosis and intracellular trafficking. The internalization of phenuiviruses into mammalian cells involves diverse pinocytic pathways and hundreds of cellular factors. The figure shows an overview of the different cellular locations of phenuivirus penetration. The entry pathways of RVFV, UUKV, and DABV appear in blue, red, and green, respectively. Sizes refer to nonvirus cargo that are typically sorted into the clathrin-mediated endocytosis, caveolin-mediated pathway, and macropinocytosis [75]. In the middle, the scales indicate the time taken by a nonvirus cargo to go from the plasma membrane to an endosomal compartment and the corresponding endosomal $\mathrm{pH}$ values [75]. DABV, Dabie virus; EEA1, early endosome antigen 1; LAMP1, lysosome-associated membrane protein 1; Rab5 and Rab7, Ras-related protein 5 and 7; RVFV, Rift Valley fever virus; UUKV, Uukuniemi virus.

Beyond highlighting the amount of work that remains to better understand the internalization mechanisms of phenuiviruses, these studies most likely reveal the ability of these viruses to use alternative endocytic pathways in the same cell or in distinct tissues. This possibility is supported by a growing amount of data obtained for unrelated viruses, such as influenza virus. The variety of endocytic processes by which viral receptors are internalized into cells as well as the expression pattern of virus receptors on the cell surface 
certainly influence the ability of phenuiviruses to enter and infect cells and tissues through one or more endocytic pathways.

\section{Intracellular Trafficking of Phenuiviral Particles}

After binding to the cell surface and internalization into the cell, the phenuiviral particles are sorted into endosomal vesicles (Figure 2). The virions travel through the endocytic machinery until they reach the endosomal compartments from which they penetrate into the cytosol. Transport from early (EEs) to late (LEs) endosomes and then to lysosomes is a complex, highly dynamic biological process. It involves hundreds of cellular factors with a wide range of functions and is still far from fully understood [76]. It is accompanied by major changes in the protein and lipid composition, concomitant with acidification of the endosomal lumen from approximately $\mathrm{pH} 6.5$ in EEs to 5.5-5.0 in LEs and lysosomes (Figure 2) [76]. Endosomal acidification has a central role in the penetration of a majority of viruses [77]. Numerous studies have demonstrated that phenuiviruses depend on low $\mathrm{pH}$ in intracellular vesicles for infection $[42,67,69,71]$. Many phenuiviruses are sensitive to the neutralization of endosomal $\mathrm{pH}$ by weak lysosomotropic bases, such as ammonium chloride and chloroquine, or by inhibitors of vacuolar-type proton pump ATPases (vATPase), such as bafilomycin A1 and concanamycin B, at extremely low concentrations (in the range of millimolar and nanomolar, respectively) (Table 3). Recent reports showed that cells deficient for RNASEK, a vATPase-associated factor, are insensitive to infection by RVFV and UUKV (Table 3) [70,74].

Several studies have clearly established that phenuiviruses transit through EEs during their journey in the endocytic machinery (Figure 2). The expression of dominant negative and constitutively active mutants of Rab5, a small GTPase necessary for EE trafficking and maturation, interrupts the intracellular transport of UUKV and therefore blocks infection by this virus [71]. Confocal microscopy images show the presence of UUKV and DABV particles in Rab5-positive EEs [64,71]. Overall, the data support the idea that phenuiviruses belong to a large group of viruses whose infectious entry depends on late endosomal maturation, known as late-penetrating viruses (L-PVs) [77]. Several phenuiviruses enter the cytosol by acid-activated penetration between 20 and $60 \mathrm{~min}$ after their internalization into cells (Table 3) $[64,67,71]$, a period of time compatible with the maturation of LEs (Figure 2) [77].

The maturation of late endosomal vesicles occurs while trafficking along the microtubules from the periphery of the cell to the nucleus. The disruption of the microtubule network by inhibitors, such as nocodazole and colcemid, results in the blockade of productive infection by UUKV and DABV (Table 3) [64,71], indicating that these viruses require an intact microtubule network to infect host cells. Another indication that supports that phenuiviruses belong to the L-PV group is that the fusion of their envelope with the endosomal membrane requires a $\mathrm{pH}$ below $5.8-5.7$ (Table 3) $[64,67,71,78]$. This acidity is typical of late endosomal vesicles [77].

It is thus apparent that many phenuiviruses penetrate their target cells from late endosomal compartments. However, the path of phenuivirus particles into the degrading branch of the endocytic machinery remains poorly characterized. VAMP3, a v-SNARE fusion protein associated in part with late endosomal vesicles [79], has been shown to be essential in the late intracellular trafficking of UUKV (Table 3) [74]. UUKV and DABV particles were visualized by confocal microscopy in intracellular vesicles positive for Rab7 (Table 3) $[64,71]$, which is considered the most critical small GTPase for LE trafficking and maturation [80]. While expression of the dominant negative T22N mutant of Rab7 has no effect on the infectious entry of UUKV, the constitutively active mutant appears to facilitate infection [71]. The presence of UUKV and DABV in endolysosomes $[41,64,71]$ raises questions about the path taken by these viruses to reach these late compartments (Table 3). The formation of endolysosomal vesicles results, at least in part, from the maturation of LEs under the control of Rab7. Several reasons could explain the inefficiency of mutants in blocking endogenous Rab7 activity, such as their mislocalization in the cell or 
the existence of several Rab7 isoforms. It is tempting to postulate that some phenuiviruses may use alternative, undescribed pathways from the late endocytic machinery to reach their compartments from where they enter the cytosol.

\section{Fusion and Penetration of Phenuiviruses into the Cytosol}

The viruses that enter cells by endocytosis must ultimately cross the membrane of endosomes to release their genome and accessory proteins into the cytosol. Phenuiviruses achieve this step with the viral glycoprotein $G_{C}$, which mediates the fusion of their envelope with the endosomal membrane [53]. Acidification is sufficient to trigger the fusion of RVFV and UUKV in cell-free in vitro experiments [67,72]. It has been shown that exposure of RVFV to acidic buffers in the absence of any target membrane leads to conformational and oligomerization changes in $\mathrm{G}_{\mathrm{C}}$ [67]. In this respect, endosomal acidification serves as a major cue to trigger fusion of many enveloped viruses but, by itself, can be insufficient. Among other factors, such as nonproton ions, intracellular receptors, specific lipids in the target endosomal membranes, or proteolytic cleavage of viral envelope proteins are sometimes required [76]. It seems that in addition to acidification, the infectious penetration of DABV relies on calcium and the cleavage of the glycoproteins $G_{N}$ and $G_{C}$ by serine proteases (Table 3) [42,65]. However, proteolytic processing may be a specificity of DABV as no other phenuivirus has been shown to rely on the cleavage of $G_{N}$ and $G_{C}$ for infection. Additionally, glycerolphospholipids and bis(monoacylglycerol)phosphate, a constituent lipid of specific LE subpopulations, facilitate RVFV and UUKV fusion with liposomes, respectively $[72,81]$.

There are at least three distinct classes of viral proteins with the capacity to mediate membrane fusion (classes I to III), each with its own mechanistic and structural specificities [82]. Significant progress has been made in recent years in the structural characterization of the $\mathrm{G}_{\mathrm{C}}$ fusion glycoprotein of phenuiviruses. The crystallographic structure of the ectodomain of the RVFV $\mathrm{G}_{\mathrm{C}}$ protein has been obtained in its two states, pre- and postfusion, with a resolution of less than $2.0 \AA[39,81]$. The structure of the postfusion form of $G_{C}$ was also determined for DABV and HRTV $[83,84]$. All these data indicate that the $\mathrm{G}_{\mathrm{C}}$ viral glycoprotein of phenuiviruses belong to the group of class II membrane fusion proteins [32].

Recently, the ectodomain of the RVFV and DABV glycoprotein $\mathrm{G}_{\mathrm{N}}$ has been crystallized and analyzed by X-ray crystallography $[53,85]$, revealing a three-domain fold reminiscent to that of the alphavirus E2 and hantavirus $\mathrm{G}_{\mathrm{N}}$ glycoprotein [86,87]. This important information made it possible to fit the crystalline structures of RVFV $G_{N}$ and $G_{C}$ in tomographic reconstructions of viral particles when inserting into target membranes after acidification [53]. A fusion model was proposed based on computer simulations predicting the passage from one structure to another. When the virus is in neutral $\mathrm{pH}$ medium, $G_{N}$ protects the hydrophobic fusion loops from the $G_{C}$ glycoprotein. $G_{N}$ would thus have a protective role, preventing premature fusion of virions during passage through the Golgi network and virus egress. Once the viral particles are in the endosomal lumen, close to a target membrane, and at a $\mathrm{pH}$ below 5.7, $\mathrm{G}_{\mathrm{N}}$ is believed to reorient to the sides. $\mathrm{G}_{\mathrm{C}}$ is then released and extends to the outer leaflet of the target endosomal membrane to insert its fusogenic unit. This model is very similar to the one proposed for the fusion of flaviviruses, which are unrelated enveloped viruses with a class II viral fusion glycoprotein [82]. Interestingly, antibodies exhibit much higher neutralizing activities in vitro and in vivo when they target $G_{N}$ rather than $G_{C}$ [88-90]. It has been proposed that anti- $G_{N}$ neutralizing antibodies block the fusogenic rearrangement of the $G_{N}-G_{C}$ array by targeting the $\mathrm{G}_{\mathrm{N}}$ distal domain [91,92].

The ectodomain of class II fusion proteins has three subdomains (I to III) and is connected to a transmembrane cytosolic tail by a short stem [93]. Analogous peptides from domain III and the stem have been successfully used to block infection by flaviviruses and by other class II viruses, such as alphaviruses and hantaviruses [94-96]. Such peptides have been shown to interfere with intramolecular interactions in viral fusion proteins 
during conformational rearrangements leading to membrane fusion. The presence of these peptides probably maintains the fusion protein in an intermediate conformation, preceding the postfusion stage, and thus prevents membrane fusion and viral infection. Similar strategies have been employed with some phenuiviruses and have given identical results. For example, peptides targeting the stem of the $G_{C}$ glycoprotein block RVFV infection [97].

Histidines in fusion proteins, including class II proteins of viral origin, act as sensors of acidification in the endosomal lumen. These residues often define the optimal $\mathrm{pH}$ of viral fusion [98]. The local environment of these histidines influences their $\mathrm{pKa}$, with values ranging widely from 4.5-7.3, and ultimately the optimal $\mathrm{pH}$ for viral particle fusion [99]. Such histidine residues have been identified in the RVFV $G_{C}$ glycoprotein by mutational analysis [67]. The $\mathrm{pH}$ threshold for penetration has been determined for several phenuiviruses using approaches that measure the fusion between viruses and liposomes, viruses and cells, or between cells and cells when they express the $G_{N}$ and $G_{C}$ glycoproteins on their surface. Fusion typically occurs at pH 5.4 for UUKV, 5.6 for DABV, and 5.7 for RVFV $[64,67,71,72]$. Ultimately, the main factor triggering fusion of most phenuiviruses appears to be the endosomal $\mathrm{pH}$.

In sum, fusion of the viral and endosomal membranes is a closely coordinated mechanism in time and space [82]. During this process, viral fusion proteins undergo multiple conformational changes. They target and harpoon the lipid bilayer of the endosome via their fusion subunit. Gradually, they pull the membranes of the endosome and virion toward each other in successive steps of narrow apposition, hemifusion, and fusion [76,82,93]. This results in the opening of pores in the endosomal membrane through which viral material is released into the cytosol. The cell is then infected, and viral replication begins.

\section{Concluding Remarks and Future Perspectives}

In this review, we summarized and provided an update of the current knowledge on the early interactions between phenuiviruses and their target cells, from the attachment of viral particles at the cell surface to their fusion and penetration into the cytosol. Although each member most likely has distinct specificities and needs, it appears that many phenuiviruses have in common the dependence on late endosomal maturation and low $\mathrm{pH}$ for the infection of target cells. However, it is clear that many aspects of phenuivirus penetration remain to be elucidated. High-throughput screens aiming to selectively inactivate genes of the human genome, for example, with approaches combining haploid cells and RNAi or the CRISPR/Cas9 system, should help to identify new factors and cellular processes important for phenuivirus entry. Such approaches have started to be applied to RVFV and UUKV $[49,74,100]$.

To target and infect a large number of different tissues and species, phenuiviruses can use multiple receptors. A few have been found in humans and other vertebrates but none in arthropods. A detailed analysis of the receptors of these viruses in both vertebrate and arthropod hosts, is therefore essential to better understand the underlying infection processes. Consequently, only the combined use of new in vitro models with ex vivo and in vivo approaches will allow us to improve our knowledge of the transmission, entry, and spread of phenuiviruses.

The characterization of viral particles transmitted by arthropods to mammals is also an important objective. Cell biology in arthropods differs significantly from that in mammals. The lipid composition of the viral envelope, and the nature of oligosaccharides in the glycoproteins on the surface of virions are factors that influence the identity of target cells, interactions with receptors, endocytosis mechanisms, and membrane fusion. For example, it has been shown that the glycosylation and conformation of the $G_{N}$ glycoprotein of UUKV differ greatly depending on whether the virus is produced in tick or mammalian cells [16]. In addition, tick cell-derived UUKV has a higher infectivity than its counterpart amplified in mammalian cells [16]. 
Studies on phenuiviruses and on other arthropod-borne viruses often involve mammalian cell-derived virus stocks, which are less relevant for studying the transmission and initial infection of these pathogens.

Ideally, preventing the spread of phenuiviruses requires approaches that target the early stages of infection. While improving our knowledge of the host spectrum and tissue tropism is essential, at the molecular level single inhibitors cannot accurately define a cellular pathway. Perturbants very often have many side effects or simply alter different processes in the cell. Only a combination of inhibitors with a well-defined profile used in combination with qualitative and quantitative approaches to visualize and analyze the very first instants of infection will make deciphering the entry mechanisms of phenuiviruses possible. These are the keys to improving our understanding of the spread of these viruses and ultimately developing new antiviral strategies.

Author Contributions: All authors discussed the manuscript content and illustrations and wrote this review. All authors have read and agreed to the published version of the manuscript.

Funding: This work was supported by INRAE starter funds, IDEX-Impulsion 2020 (University of Lyon), and FINOVI (Fondation pour l'Université de Lyon), all to P.Y.L. This work was also supported by CellNetworks Research Group funds and the Deutsche Forschungsgemeinschaft (DFG) funding (grant numbers LO-2338/1-1 and LO-2338/3-1) awarded to P.Y.L. It was also supported by a Chinese Scholarship Council fellowship to Q.X.

Conflicts of Interest: The authors declare no conflict of interest. The funders had no role in the design of the study; in the collection, analyses, or interpretation of data; in the writing of the manuscript; or in the decision to publish the results.

\section{References}

1. ICTV. 10th Report of the International Committee for Taxonomy of Viruses. 2017. Available online: https://ictv.global/report/ (accessed on 15 January 2021).

2. Marklewitz, M.; Palacios, G.; Ebihara, H.; Kuhn, J.H.; Junglen, S. Create Four New Genera, Create Seventy-Nine New Species, Rename/Move Seven Species, Rename/Move Three Genera and Abolish One Genus in the Family Phenuiviridae. In Order Bunyavirales; ICTV: Berlin, Germany, 2019. [CrossRef]

3. Léger, P.; Lozach, P.-Y. Bunyaviruses: From transmission by arthropods to virus entry into the mammalian host first-target cells. Future Virol. 2015, 10, 859-881. [CrossRef]

4. Elliott, R.M.; Brennan, B. Emerging phleboviruses. Curr. Opin. Virol. 2014, 5, 50-57. [CrossRef] [PubMed]

5. Yu, X.-J.; Liang, M.-F.; Zhang, S.-Y.; Liu, Y.; Li, J.-D.; Sun, Y.-L.; Zhang, L.; Zhang, Q.-F.; Popov, V.L.; Li, C.; et al. Fever with Thrombocytopenia Associated with a Novel Bunyavirus in China. N. Engl. J. Med. 2011, 364, 1523-1532. [CrossRef]

6. Moriconi, M.; Rugna, G.; Calzolari, M.; Bellini, R.; Albieri, A.; Angelini, P.; Cagarelli, R.; Landini, M.P.; Charrel, R.N.; Varani, S. Phlebotomine sand fly-borne pathogens in the Mediterranean Basin: Human leishmaniasis and phlebovirus infections. PLoS Negl. Trop. Dis. 2017, 11, e0005660. [CrossRef]

7. Wright, D.; Kortekaas, J.; Bowden, T.A.; Warimwe, G.M. Rift Valley fever: Biology and epidemiology. J. Gen. Virol. 2019, 100, 1187-1199. [CrossRef]

8. $\quad$ Léger, P.; Nachman, E.; Richter, K.; Tamietti, C.; Koch, J.; Burk, R.; Kummer, S.; Xin, Q.; Stanifer, M.; Bouloy, M.; et al. NSs amyloid formation is associated with the virulence of Rift Valley fever virus in mice. Nat. Commun. 2020, 11, 1-19. [CrossRef]

9. Zhang, Y.-Z.; Zhou, D.-J.; Qin, X.-C.; Tian, J.-H.; Xiong, Y.; Wang, J.-B.; Chen, X.-P.; Gao, D.-Y.; He, Y.-W.; Jin, D.; et al. The Ecology, Genetic Diversity, and Phylogeny of Huaiyangshan Virus in China. J. Virol. 2011, 86, 2864-2868. [CrossRef] [PubMed]

10. Savage, H.M.; Godsey, J.M.S.; Lambert, A.; Panella, N.A.; Burkhalter, K.L.; Harmon, J.R.; Lash, R.R.; Ashley, D.C.; Nicholson, W.L. First Detection of Heartland Virus (Bunyaviridae: Phlebovirus) from Field Collected Arthropods. Am. J. Trop. Med. Hyg. 2013, 89, 445-452. [CrossRef] [PubMed]

11. McMullan, L.K.; Folk, S.M.; Kelly, A.J.; MacNeil, A.; Goldsmith, C.S.; Metcalfe, M.G.; Batten, B.C.; Albariño, C.G.; Zaki, S.R.; Rollin, P.E.; et al. A New Phlebovirus Associated with Severe Febrile Illness in Missouri. N. Engl. J. Med. 2012, 367, 834-841. [CrossRef] [PubMed]

12. Liu, Q.; He, B.; Huang, S.-Y.; Wei, F.; Zhu, X.-Q. Severe fever with thrombocytopenia syndrome, an emerging tick-borne zoonosis. Lancet Infect. Dis. 2014, 14, 763-772. [CrossRef]

13. Muehlenbachs, A.; Fata, C.R.; Lambert, A.J.; Paddock, C.D.; Velez, J.O.; Blau, D.M.; Staples, J.E.; Karlekar, M.B.; Bhatnagar, J.; Nasci, R.S.; et al. Heartland Virus-Associated Death in Tennessee. Clin. Infect. Dis. 2014, 59, 845-850. [CrossRef]

14. Wang, J.; Selleck, P.; Yu, M.; Ha, W.; Rootes, C.; Gales, R.; Wise, T.; Crameri, S.; Chen, H.; Broz, I.; et al. Novel Phlebovirus with Zoonotic Potential Isolated from Ticks, Australia. Emerg. Infect. Dis. 2014, 20, 1040-1043. [CrossRef] [PubMed] 
15. Oker-Blom, N.; Salminen, A.; Brummer-Korvenkontio, M.; Kaeaeriaeinen, L.; Weckstroem, P. Isolation of Some Viruses Other than Typical Tick-Borne Encephalitis Viruses from Ixodes Ricinus Ticks in Finland. Ann. Med. Exp. Biol. Pennine 1964, 42, 109-112.

16. Mazelier, M.; Rouxel, R.N.; Zumstein, M.; Mancini, R.; Bell-Sakyi, L.; Lozach, P.-Y. Uukuniemi Virus as a Tick-Borne Virus Model. J. Virol. 2016, 90, 6784-6798. [CrossRef]

17. Uckeley, Z.M.; Moeller, R.; Kühn, L.I.; Nilsson, E.; Robens, C.; Lasswitz, L.; Lindqvist, R.; Lenman, A.; Passos, V.; Voss, Y.; et al. Quantitative Proteomics of Uukuniemi Virus-host Cell Interactions Reveals GBF1 as Proviral Host Factor for Phleboviruses. Mol. Cell Proteom. 2019, 18, 2401-2417. [CrossRef]

18. Rezelj, V.V.; Överby, A.K.; Elliott, R.M. Generation of Mutant Uukuniemi Viruses Lacking the Nonstructural Protein NSs by Reverse Genetics Indicates that NSs is a Weak Interferon Antagonist. J. Virol. 2015, 89, 4849-4856. [CrossRef]

19. Verani, P.; Ciufolini, M.G.; Nicoletti, L.; Balducci, M.; Sabatinelli, G.; Coluzzi, M.; Paci, P.; Amaducci, L. Ecological and epidemiological studies of Toscana virus, an arbovirus isolated from Phlebotomus. Ann. Ist. Super. Sanità 1982, 18, 397-399. [PubMed]

20. Charrel, R.; Berenger, J.-M.; Laroche, M.; Ayhan, N.; Bitam, I.; Delaunay, P.; Parola, P. Neglected vector-borne bacterial diseases and arboviruses in the Mediterranean area. New Microbes New Infect. 2018, 26, S31-S36. [CrossRef]

21. Ayhan, N.; Charrel, R. An update on Toscana virus distribution, genetics, medical and diagnostic aspects. Clin. Microbiol. Infect. 2020, 26, 1017-1023. [CrossRef]

22. Woelfl, F.; Léger, P.; Oreshkova, N.; Pahmeier, F.; Windhaber, S.; Koch, J.; Stanifer, M.; Sosa, G.R.; Uckeley, Z.M.; Rey, F.A.; et al. Novel Toscana Virus Reverse Genetics System Establishes NSs as an Antagonist of Type I Interferon Responses. Viruses 2020, 12, 400. [CrossRef]

23. Lumley, S.; Horton, D.L.; Hernandez-Triana, L.L.M.; Johnson, N.; Fooks, A.R.; Hewson, R. Rift Valley fever virus: Strategies for maintenance, survival and vertical transmission in mosquitoes. J. Gen. Virol. 2017, 98, 875-887. [CrossRef]

24. Daubney, R.; Hudson, J.R. Enzootic Hepatitis or Rift Valley Fever. An Undescribed Virus Disease of Sheep, Cattle and Man from East Africa. J. Pathol. Bacteriol. 1931, 34, 545-579. [CrossRef]

25. Gür, S.; Kale, M.; Erol, N.; Yapici, O.; Mamak, N.; Yavru, S. The first serological evidence for Rift Valley fever infection in the camel, goitered gazelle and Anatolian water buffaloes in Turkey. Trop. Anim. Health Prod. 2017, 49, 1531-1535. [CrossRef]

26. World Health Organization. Blueprint for RED Preparedness and Response to Public Health Emergencies Due to Highly Infectious Pathogens; World Health Organization: Geneva, Switzerland, 2015.

27. Albornoz, A.; Hoffmann, A.B.; Lozach, P.-Y.; Tischler, N.D. Early Bunyavirus-Host Cell Interactions. Viruses 2016, 8, 143. [CrossRef]

28. Maes, P.; Adkins, S.; Alkhovsky, S.V.; Avšič-Županc, T.; Ballinger, M.J.; Bente, D.A.; Beer, M.; Bergeron, É.; Blair, C.D.; Briese, T.; et al. Taxonomy of the order Bunyavirales: Second update 2018. Arch. Virol. 2019, 164, 927-941. [CrossRef]

29. Brault, A.C.; Savage, H.M.; Duggal, N.K.; Eisen, R.J.; Staples, J.E. Heartland Virus Epidemiology, Vector Association, and Disease Potential. Viruses 2018, 10, 498. [CrossRef] [PubMed]

30. Horne, K.M.; VanLandingham, D.L. Bunyavirus-Vector Interactions. Viruses 2014, 6, 4373-4397. [CrossRef] [PubMed]

31. Ayhan, N.; Prudhomme, J.; Laroche, L.; Bañuls, A.-L.; Charrel, R.N. Broader Geographical Distribution of Toscana Virus in the Mediterranean Region Suggests the Existence of Larger Varieties of Sand Fly Vectors. Microorganisms 2020, 8, 114. [CrossRef] [PubMed]

32. Spiegel, M.; Plegge, T.; Pöhlmann, S. The Role of Phlebovirus Glycoproteins in Viral Entry, Assembly and Release. Viruses 2016, 8 , 202. [CrossRef] [PubMed]

33. Guardado-Calvo, P.; Rey, F.A. The Envelope Proteins of the Bunyavirales. Adv. Appl. Microbiol. 2017, 98, 83-118. [CrossRef]

34. Xu, B.; Liu, L.; Huang, X.; Ma, H.; Zhang, Y.; Du, Y.; Wang, P.; Tang, X.; Wang, H.; Kang, K.; et al. Metagenomic Analysis of Fever, Thrombocytopenia and Leukopenia Syndrome (FTLS) in Henan Province, China: Discovery of a New Bunyavirus. PLoS Pathog. 2011, 7, e1002369. [CrossRef]

35. Hornak, K.E.; Lanchy, J.-M.; Lodmell, J.S. RNA Encapsidation and Packaging in the Phleboviruses. Viruses 2016, 8, 194. [CrossRef]

36. Freiberg, A.N.; Sherman, M.B.; Morais, M.C.; Holbrook, M.R.; Watowich, S.J. Three-Dimensional Organization of Rift Valley Fever Virus Revealed by Cryoelectron Tomography. J. Virol. 2008, 82, 10341-10348. [CrossRef]

37. Huiskonen, J.T.; Överby, A.K.; Weber, F.; Grünewald, K. Electron Cryo-Microscopy and Single-Particle Averaging of Rift Valley Fever Virus: Evidence for GN-GC Glycoprotein Heterodimers. J. Virol. 2009, 83, 3762-3769. [CrossRef]

38. Overby, A.K.; Pettersson, R.F.; Grünewald, K.; Huiskonen, J.T. Insights into bunyavirus architecture from electron cryotomography of Uukuniemi virus. Proc. Natl. Acad. Sci. USA 2008, 105, 2375-2379. [CrossRef] [PubMed]

39. Dessau, M.; Modis, Y. Crystal structure of glycoprotein C from Rift Valley fever virus. Proc. Natl. Acad. Sci. USA 2013, 110, 1696-1701. [CrossRef] [PubMed]

40. Boulant, S.; Stanifer, M.; Lozach, P.-Y. Dynamics of Virus-Receptor Interactions in Virus Binding, Signaling, and Endocytosis. Viruses 2015, 7, 2794-2815. [CrossRef]

41. Lozach, P.-Y.; Kühbacher, A.; Meier, R.; Mancini, R.; Bitto, D.; Bouloy, M.; Helenius, A. DC-SIGN as a receptor for phlebo-viruses. Cell Host Microbe 2011, 10, 75-88. [CrossRef]

42. Hofmann, H.; Li, X.; Zhang, X.; Liu, W.; Kühl, A.; Kaup, F.; Soldan, S.S.; González-Scarano, F.; Weber, F.; He, Y.; et al. Severe fever with thrombocytopenia virus glycoproteins are targeted by neutralizing antibodies and can use DC-SIGN as a receptor for pH-dependent entry into human and animal cell lines. J. Virol. 2013, 87, 4384-4394. [CrossRef] [PubMed] 
43. Tani, H.; Shimojima, M.; Fukushi, S.; Yoshikawa, T.; Fukuma, A.; Taniguchi, S.; Morikawa, S.; Saijo, M. Characterization of Glycoprotein-Mediated Entry of Severe Fever with Thrombocytopenia Syndrome Virus. J. Virol. 2016, 90, 5292-5301. [CrossRef]

44. Suzuki, T.; Sato, Y.; Sano, K.; Arashiro, T.; Katano, H.; Nakajima, N.; Shimojima, M.; Kataoka, M.; Takahashi, K.; Wada, Y.; et al. Severe fever with thrombocytopenia syndrome virus targets B cells in lethal human infections. J. Clin. Investig. 2020, 130, 799-812. [CrossRef] [PubMed]

45. Phoenix, I.; Nishiyama, S.; Lokugamage, N.; Hill, T.E.; Huante, M.B.; Slack, O.A.; Carpio, V.H.; Freiberg, A.N.; Ikegami, T. N-Glycans on the Rift Valley Fever Virus Envelope Glycoproteins Gn and Gc Redundantly Support Viral Infection via DC-SIGN. Viruses 2016, 8, 149. [CrossRef]

46. Shimojima, M.; Sugimoto, S.; Taniguchi, S.; Yoshikawa, T.; Kurosu, T.; Saijo, M. Efficient functional screening of a cellular cDNA library to identify severe fever with thrombocytopenia syndrome virus entry factors. Sci. Rep. 2020, 10, 1-12. [CrossRef]

47. Léger, P.; Tetard, M.; Youness, B.; Cordes, N.; Rouxel, R.N.; Flamand, M.; Lozach, P.-Y. Differential Use of the C-Type Lectins L-SIGN and DC-SIGN for Phlebovirus Endocytosis. Traffic 2016, 17, 639-656. [CrossRef]

48. De Boer, S.M.; Kortekaas, J.; De Haan, C.A.M.; Rottier, P.J.M.; Moormann, R.J.M.; Bosch, B.J. Heparan Sulfate Facilitates Rift Valley Fever Virus Entry into the Cell. J. Virol. 2012, 86, 13767-13771. [CrossRef]

49. Riblett, A.M.; Blomen, V.A.; Jae, L.T.; Altamura, L.A.; Doms, R.W.; Brummelkamp, T.R.; Wojcechowskyj, J.A. A Haploid Genetic Screen Identifies Heparan Sulfate Proteoglycans Supporting Rift Valley Fever Virus Infection. J. Virol. 2016, 90, 1414-1423. [CrossRef] [PubMed]

50. Pietrantoni, A.; Fortuna, C.; Remoli, M.E.; Ciufolini, M.G.; Superti, F. Bovine Lactoferrin Inhibits Toscana Virus Infection by Binding to Heparan Sulphate. Viruses 2015, 7, 480-495. [CrossRef] [PubMed]

51. Sun, Y.; Qi, Y.; Liu, C.; Gao, W.; Chen, P.; Fu, L.; Peng, B.; Wang, H.; Jing, Z.; Zhong, G.; et al. Nonmuscle Myosin Heavy Chain IIA Is a Critical Factor Contributing to the Efficiency of Early Infection of Severe Fever with Thrombocytopenia Syndrome Virus. J. Virol. 2013, 88, 237-248. [CrossRef]

52. Švajger, U.; Anderluh, M.; Jeras, M.; Obermajer, N. C-type lectin DC-SIGN: An adhesion, signalling and antigen-uptake molecule that guides dendritic cells in immunity. Cell. Signal. 2010, 22, 1397-1405. [CrossRef] [PubMed]

53. Halldorsson, S.; Li, S.; Li, M.; Harlos, K.; Bowden, T.A.; Huiskonen, J.T. Shielding and activation of a viral membrane fusion protein. Nat. Commun. 2018, 9, 1-9. [CrossRef]

54. Pokidysheva, E.; Zhang, Y.; Battisti, A.J.; Bator-Kelly, C.M.; Chipman, P.R.; Xiao, C.; Gregorio, G.G.; Hendrickson, W.A.; Kuhn, R.J.; Rossmann, M.G. Cryo-EM Reconstruction of Dengue Virus in Complex with the Carbohydrate Recognition Domain of DC-SIGN. Cell 2006, 124, 485-493. [CrossRef] [PubMed]

55. Pustylnikov, S.; Sagar, D.; Jain, P.; Khan, Z.K. Targeting the C-type lectins-mediated host-pathogen interactions with dextran. J. Pharm. Pharm. Sci. Publ. Can. Soc. Pharm. Sci. 2014, 17, 371-392. [CrossRef] [PubMed]

56. Silvas, J.A.; Popov, V.L.; Paulucci-Holthauzen, A.; Aguilar, P.V. Extracellular Vesicles Mediate Receptor-Independent Transmission of Novel Tick-Borne Bunyavirus. J. Virol. 2015, 90, 873-886. [CrossRef]

57. Hoffmann, A.B.; Mazelier, M.; Léger, P.; Lozach, P.-Y. Deciphering Virus Entry with Fluorescently Labeled Viral Particles. In Advanced Structural Safety Studies; Humana Press: New York, NY, USA, 2018; pp. 159-183.

58. Drake, M.J.; Brennan, B.; Briley, J.K.; Bart, S.M.; Sherman, E.; Szemiel, A.M.; Minutillo, M.; Bushman, F.D.; Bates, P. A role for glycolipid biosynthesis in severe fever with thrombocytopenia syndrome virus entry. PLoS Pathog. 2017, 13, e1006316. [CrossRef] [PubMed]

59. Lozach, P.-Y.; Burleigh, L.; Staropoli, I.; Navarro-Sanchez, E.; Harriague, J.; Virelizier, J.-L.; Rey, F.A.; Desprès, P.; ArenzanaSeisdedos, F.; Amara, A. Dendritic Cell-specific Intercellular Adhesion Molecule 3-grabbing Non-integrin (DC-SIGN)-mediated Enhancement of Dengue Virus Infection Is Independent of DC-SIGN Internalization Signals. J. Biol. Chem. 2005, 280, 23698-23708. [CrossRef]

60. Staudt, C.; Puissant, E.; Boonen, M. Subcellular Trafficking of Mammalian Lysosomal Proteins: An Extended View. Int. J. Mol. Sci. 2016, 18, 47. [CrossRef]

61. Braulke, T.; Bonifacino, J.S. Sorting of lysosomal proteins. Biochim. Biophys. Acta Mol. Cell Res. 2009, 1793, 605-614. [CrossRef]

62. Itano, M.S.; Neumann, A.K.; Liu, P.; Zhang, F.; Gratton, E.; Parak, W.J.; Thompson, N.L.; Jacobson, K. DC-SIGN and Influenza Hemagglutinin Dynamics in Plasma Membrane Microdomains Are Markedly Different. Biophys. J. 2011, 100, 2662-2670. [CrossRef]

63. Liu, P.; Ridilla, M.; Patel, P.; Betts, L.; Gallichotte, E.; Shahidi, L.; Thompson, N.L.; Jacobson, K. Beyond attachment: Roles of DC-SIGN in dengue virus infection. Traffic 2017, 18, 218-231. [CrossRef]

64. Liu, J.; Xu, M.; Tang, B.; Hu, L.; Deng, F.; Wang, H.; Pang, D.-W.; Hu, Z.; Wang, M.; Zhou, Y. Single-Particle Tracking Reveals the Sequential Entry Process of the Bunyavirus Severe Fever with Thrombocytopenia Syndrome Virus. Small 2019, 15, e1803788. [CrossRef] [PubMed]

65. Li, H.; Zhang, L.-K.; Li, S.-F.; Zhang, S.-F.; Wan, W.-W.; Zhang, Y.-L.; Xin, Q.-L.; Dai, K.; Hu, Y.-Y.; Wang, Z.-B.; et al. Calcium channel blockers reduce severe fever with thrombocytopenia syndrome virus (SFTSV) related fatality. Cell Res. 2019, 29, 739-753. [CrossRef] [PubMed]

66. Liu, T.; Li, J.; Liu, Y.; Qu, Y.; Li, A.; Li, C.; Zhang, Q.; Wu, W.; Li, J.; Liu, Y.; et al. SNX11 Identified as an Essential Host Factor for SFTS Virus Infection by CRISPR Knockout Screening. Virol. Sin. 2019, 34, 508-520. [CrossRef] [PubMed] 
67. De Boer, S.M.; Kortekaas, J.; Spel, L.; Rottier, P.J.M.; Moormann, R.J.M.; Bosch, B.J. Acid-Activated Structural Reorganization of the Rift Valley Fever Virus Gc Fusion Protein. J. Virol. 2012, 86, 13642-13652. [CrossRef]

68. Filone, C.M.; Hanna, S.L.; Caino, M.C.; Bambina, S.; Doms, R.W.; Cherry, S. Rift Valley Fever Virus Infection of Human Cells and Insect Hosts Is Promoted by Protein Kinase C Epsilon. PLoS ONE 2010, 5, e15483. [CrossRef]

69. Harmon, B.; Schudel, B.R.; Maar, D.; Kozina, C.; Ikegami, T.; Tseng, C.-T.K.; Negrete, O.A. Rift Valley Fever Virus Strain MP-12 Enters Mammalian Host Cells via Caveola-Mediated Endocytosis. J. Virol. 2012, 86, 12954-12970. [CrossRef] [PubMed]

70. Hackett, B.A.; Yasunaga, A.; Panda, D.; Tartell, M.A.; Hopkins, K.C.; Hensley, S.E.; Cherry, S. RNASEK is required for internalization of diverse acid-dependent viruses. Proc. Natl. Acad. Sci. USA 2015, 112, 7797-7802. [CrossRef]

71. Lozach, P.-Y.; Mancini, R.; Bitto, D.; Meier, R.; Oestereich, L.; Overby, A.K.; Pettersson, R.F.; Helenius, A. Entry of bunya-viruses into mammalian cells. Cell Host Microbe 2010, 7, 488-499. [CrossRef] [PubMed]

72. Bitto, D.; Halldorsson, S.; Caputo, A.; Huiskonen, J.T. Low pH and Anionic Lipid-dependent Fusion of Uukuniemi Phlebovirus to Liposomes. J. Biol. Chem. 2016, 291, 6412-6422. [CrossRef]

73. Yamauchi, Y.; Boukari, H.; Banerjee, I.; Sbalzarini, I.F.; Horvath, P.; Helenius, A. Histone deacetylase 8 is required for cen-trosome cohesion and influenza A virus entry. PLoS Pathog. 2011, 7, e1002316. [CrossRef]

74. Meier, R.; Franceschini, A.; Horvath, P.; Tetard, M.; Mancini, R.; Von Mering, C.; Helenius, A.; Lozach, P.-Y. Genome-Wide Small Interfering RNA Screens Reveal VAMP3 as a Novel Host Factor Required for Uukuniemi Virus Late Penetration. J. Virol. 2014, 88, 8565-8578. [CrossRef]

75. Mercer, J.; Schelhaas, M.; Helenius, A. Virus Entry by Endocytosis. Annu. Rev. Biochem. 2010, 79, 803-833. [CrossRef]

76. White, J.M.; Whittaker, G.R. Fusion of Enveloped Viruses in Endosomes. Traffic 2016, 17, 593-614. [CrossRef]

77. Lozach, P.-Y.; Huotari, J.; Helenius, A. Late-penetrating viruses. Curr. Opin. Virol. 2011, 1, 35-43. [CrossRef]

78. Liu, L.; Celma, C.C.; Roy, P. Rift Valley fever virus structural proteins: Expression, characterization and assembly of recombinant proteins. Virol. J. 2008, 5, 82. [CrossRef] [PubMed]

79. Valdez, A.C.; Cabaniols, J.P.; Brown, M.J.; A Roche, P. Syntaxin 11 is associated with SNAP-23 on late endosomes and the trans-Golgi network. J. Cell Sci. 1999, 112, 845-854. [PubMed]

80. Wang, T.; Ming, Z.; XiaoChun, W.; Hong, W. Rab7: Role of its protein interaction cascades in endo-lysosomal traffic. Cell. Signal. 2011, 23, 516-521. [CrossRef] [PubMed]

81. Guardado-Calvo, P.; Atkovska, K.; Jeffers, S.A.; Grau, N.; Backovic, M.; Pérez-Vargas, J.; De Boer, S.M.; Tortorici, M.A.; PehauArnaudet, G.; Lepault, J.; et al. A glycerophospholipid-specific pocket in the RVFV class II fusion protein drives target membrane insertion. Science 2017, 358, 663-667. [CrossRef]

82. Harrison, S.C. Viral membrane fusion. Virology 2015, 479-480, 498-507. [CrossRef]

83. Zhu, Y.; Wu, Y.; Chai, Y.; Qi, J.; Peng, R.; Feng, W.-H.; Gao, G.F. The Postfusion Structure of the Heartland Virus Gc Glycoprotein Supports Taxonomic Separation of the Bunyaviral Families Phenuiviridae and Hantaviridae. J. Virol. 2018, 92. [CrossRef]

84. Halldorsson, S.; Behrens, A.-J.; Harlos, K.; Huiskonen, J.T.; Elliott, R.M.; Crispin, M.; Brennan, B.; Bowden, T.A. Structure of a phleboviral envelope glycoprotein reveals a consolidated model of membrane fusion. Proc. Natl. Acad. Sci. USA 2016, 113, 7154-7159. [CrossRef]

85. Wu, Y.; Zhu, Y.; Gao, F.; Jiao, Y.; Oladejo, B.O.; Chai, Y.; Bi, Y.; Lu, S.; Dong, M.; Zhang, C.; et al. Structures of phlebovirus glycoprotein Gn and identi-fication of a neutralizing antibody epitope. Proc. Natl. Acad. Sci. USA 2017, 114, E7564-E7573. [CrossRef]

86. Voss, J.E.; Vaney, M.-C.; Duquerroy, S.; Vonrhein, C.; Girard-Blanc, C.; Crublet, E.; Thompson, A.; Bricogne, G.; Rey, F.A. Glycoprotein organization of Chikungunya virus particles revealed by X-ray crystallography. Nat. Cell Biol. 2010, 468, 709-712. [CrossRef]

87. Li, S.; Rissanen, I.; Zeltina, A.; Hepojoki, J.; Raghwani, J.; Harlos, K.; Pybus, O.G.; Huiskonen, J.T.; Bowden, T.A. A Molecular Level Account of the Antigenic Hantaviral Surface. Cell Rep. 2016, 15, 959-967. [CrossRef]

88. Wang, Q.; Ma, T.; Wu, Y.; Chen, Z.; Zeng, H.; Tong, Z.; Gao, F.; Qi, J.; Zhao, Z.; Chai, Y.; et al. Neutralization mechanism of human monoclonal antibodies against Rift Valley fever virus. Nat. Microbiol. 2019, 4, 1231-1241. [CrossRef] [PubMed]

89. Gutjahr, B.; Keller, M.; Rissmann, M.; von Arnim, F.; Jäckel, S.; Reiche, S.; Ulrich, R.; Groschup, M.H.; Eiden, M. Two monoclonal antibodies against glycoprotein Gn protect mice from Rift Valley Fever challenge by cooperative effects. PLoS Negl. Trop. Dis. 2020, 14, e0008143. [CrossRef] [PubMed]

90. Wright, D.; Allen, E.R.; Clark, M.H.; Gitonga, J.N.; Karanja, H.K.; Hulswit, R.J.; Taylor, I.; Biswas, S.; Marshall, J.; Mwololo, D.; et al. Naturally Acquired Rift Valley Fever Virus Neutralizing Antibodies Predominantly Target the Gn Glycoprotein. iScience 2020, 23, 101669. [CrossRef]

91. Allen, E.R.; Krumm, S.A.; Raghwani, J.; Halldorsson, S.; Elliott, A.; Graham, V.A.; Koudriakova, E.; Harlos, K.; Wright, D.; Warimwe, G.M.; et al. A Protective Monoclonal Antibody Targets a Site of Vulnerability on the Surface of Rift Valley Fever Virus. Cell Rep. 2018, 25, 3750-3758. [CrossRef] [PubMed]

92. Hao, M.; Zhang, G.; Zhang, S.; Chen, Z.; Chi, X.; Dong, Y.; Fan, P.; Liu, Y.; Chen, Y.; Song, X.; et al. Characterization of Two Neutralizing Antibodies against Rift Valley Fever Virus Gn Protein. Viruses 2020, 12, 259. [CrossRef] [PubMed]

93. Kielian, M. Mechanisms of Virus Membrane Fusion Proteins. Annu. Rev. Virol. 2014, 1, 171-189. [CrossRef]

94. Schmidt, A.G.; Yang, P.L.; Harrison, S.C. Peptide Inhibitors of Dengue-Virus Entry Target a Late-Stage Fusion Intermediate. PLoS Pathog. 2010, 6, e1000851. [CrossRef] 
95. Liao, M.; Kielian, M. Domain III from class II fusion proteins functions as a dominant-negative inhibitor of virus membrane fusion. J. Cell Biol. 2005, 171, 111-120. [CrossRef] [PubMed]

96. Barriga, G.P.; Villalón-Letelier, F.; Márquez, C.L.; Bignon, E.A.; Acuna, R.; Ross, B.H.; Monasterio, O.; Mardones, G.A.; Vidal, S.E.; Tischler, N.D. Inhibition of the Hantavirus Fusion Process by Predicted Domain III and Stem Peptides from Glycoprotein Gc. PLoS Negl. Trop. Dis. 2016, 10, e0004799. [CrossRef] [PubMed]

97. Koehler, J.W.; Smith, J.M.; Ripoll, D.R.; Spik, K.W.; Taylor, S.L.; Badger, C.V.; Grant, R.J.; Ogg, M.M.; Wallqvist, A.; Guttieri, M.C.; et al. A Fusion-Inhibiting Peptide against Rift Valley Fever Virus Inhibits Multiple, Diverse Viruses. PLoS Negl. Trop. Dis. 2013, 7, e2430. [CrossRef] [PubMed]

98. Kampmann, T.; Mueller, D.S.; Mark, A.E.; Young, P.R.; Kobe, B. The Role of histidine residues in low-pH-mediated viral membrane fusion. Structure 2006, 14, 1481-1487. [CrossRef]

99. Edgcomb, S.P.; Murphy, K.P. Variability in the pKa of histidine side-chains correlates with burial within proteins. Proteins Struct. Funct. Bioinform. 2002, 49, 1-6. [CrossRef]

100. Hopkins, K.C.; McLane, L.M.; Maqbool, T.; Panda, D.; Gordesky-Gold, B.; Cherry, S. A genome-wide RNAi screen reveals that mRNA decapping restricts bunyaviral replication by limiting the pools of Dcp2-accessible targets for cap-snatching. Genes Dev. 2013, 27, 1511-1525. [CrossRef] 